\title{
Teologiczna ikona św. Józefa w ujęciu Jana Pawła II
}

Chociaż od publikacji adhortacji apostolskiej Redemptoris custos Jana Pawła II minęło ponad trzydzieści lat ${ }^{2}$, ogłoszenie przez papieża Franciszka roku 2021 jako Roku Świętego Józefa oraz sto pięćdziesiąta rocznica ogłoszenia przez Piusa IX św. Józefa patronem Kościoła powszechnego przywodzą na myśl wyżej wymieniony dokument, który pomimo umiarkowanej ilości opracowań ${ }^{3}$ (również w języku polskim ${ }^{4}$ ), zasługuje na naszą uwagę. Celem niniejszego opracowania

${ }^{1}$ Bogusław Kochaniewicz - prof. dr hab., pracownik w Zakładzie Teologii Systematycznej Wydziału Teologicznego UAM w Poznaniu, e-mail: bogusk@amu.edu.pl, ORCID: 0000-00034740-6510.

2 Jan Paweł II, Adhortacja apostolska Redemptoris custos, Libreria Editrice Vaticana 1990 (dalej: RC).

${ }^{3}$ T. Stramare, A vent'anni dalla „Redemptoris custos”, w: Święty Józef - Patron na nasze czasy. Akta X Międzynarodowego Kongresu Józefologicznego. Kalisz 27 września - 4 października 2009, Kalisz 2010, s. 37-50. Należy zaznaczyć numer monograficzny czasopisma „Estudios Josefinos" 44/87-88(1990) poświęcony adhortacji Redemptoris custos. T. Stramare, San Giuseppe nel mistero di Dio, Casale Monferrato 1992; T. Stramare, Syn Józefa z Nazaretu, Kraków 1980; T. Stramare, Ewangelia tajemnic ukrytego życia Jezusa (Mateusz i Lukasz 1-2), Poznań 2012; T. Stramare, Die Theologie des Mysteriums - „Passwort” fur die Lekture von „Redemptoris custos", w: Die Bedeutung des hl. Joseph in der Heilsgeschichte. Akten des IX. Internationalen Symposions uber den heiligen Joseph (25 September bis 2 Oktober 2005 Kevelaer/Deutschland), Frankfurt 2006, s. 243-256.

${ }^{4}$ R. M. Kolinko, Św. Józef wzorem życia wewnętrznego i patronem na nasze czasy dla osób konsekrowanych na podstawie adhortacji apostolskiej Jana Pawla II „Redemptoris custos”, w: Święty Józef - Patron na nasze czasy. Akta X Międzynarodowego Kongresu Józefologicznego. Kalisz 27 września - 4 października 2009, Kalisz 2010, s. 705-712; W. Czamara, Główne idee adhortacji apostolskiej Jana Pawła II „,Redemptoris custos”, „Ateneum Kapłańskie” 132(1999), z. 1, s. 6-12; J. Hadryś, Święty Józef wzorem człowieka zatroskanego o życie w świetle „Redemptoris custos”, w: Bądźcie solidarni z życiem. W dziesiąta rocznicę przemówienia Jana Pawta II 
będzie analiza interpretacji postaci świętego patriarchy przedstawiona w wymienionym dokumencie. Badaniem objęto również źródła, którymi posłużył się papież w konstrukcji teologicznego obrazu. Ponieważ w literaturze przedmiotu brakuje opracowań podejmujących ten temat, należy wyrazić nadzieję, że niniejsze studium będzie przyczynkiem uzupełniającym refleksję nad sposobem prowadzenia teologicznej konstrukcji obrazu świętego patriarchy. Ze względu na bogactwo materiału, w przeprowadzonych badaniach celowo pominięto wypowiedzi na interesujący nas temat zawarte w homiliach, środowych katechezach bądź w alokucjach wygłoszonych przez papieża Wojtyłę przed modlitwą Anioł Pański.

\section{Teologiczny dyptych}

Analiza struktury adhortacji pozwala stwierdzić, że postać św. Józefa została ukazana w dwóch uzupełniających się częściach, to znaczy w tajemnicy Chrystusa i w tajemnicy Kościoła. Podział ten odzwierciedla analogiczną dystynkcję, zastosowaną w ósmym rozdziale Lumen gentium, w odniesieniu do postaci Najświętszej Maryi Panny.

Centralnym punktem, w którym zbiegają się wszystkie linie dokumentu, jest postać Odkupiciela, w świetle którego zaprezentowano postać św. Józefa. Potwierdza to tytuł - Redemptoris custos. Takie ujęcie jest kompatybilne z soborową konstytucją o Objawieniu, w której czytamy: „Najgłębsza zaś prawda o Bogu i o zbawieniu człowieka jaśnieje nam przez to objawienie w osobie Chrystusa, który jest zarazem pośrednikiem i pełnią całego objawienia"s. Natomiast Katechizm Kościoła Katolickiego dodał, że całe życie Chrystusa jest tajemnicą Odkupienia ${ }^{6}$. Jan Paweł II w swojej refleksji opiera się na powyższych przesłankach, co potwierdzają tytuły jego pierwszych encyklik (Redemptor hominis, Redemptoris Mater, Redemptoris custos, Redemptoris missio) ${ }^{7}$. Wszystkie tajemnice życia Chrystusa, począwszy od wcielenia aż po zmartwychwstanie,

w Kaliszu w obronie życia, red. D. Bryl, J. Troska, Poznań 2007, s. 137-149; D. Brzeziński, Udziat świętego Józefa w zbawczych planach Boga $w$ świetle adhortacji apostolskiej „Redemptoris custos”, „Studia Liturgiczne” 12(2016), s. 13-22; W. Czamara, Gtówne idee adhortacji apostolskiej Jana Pawta II „Redemptoris custos”, „Collectanea Theologica” 69(1999), nr 1, s. 151-156; W. Cichosz, Ł. Rumian, Pedagogia Świętego Józefa w świetle adhortacji apostolskiej „,Redemptoris custos”, „Teologia i Człowiek” 50(2020)2, s. 65-90.

${ }^{5}$ Sobór Watykański II, Konstytucja dogmatyczna o Objawieniu Bożym Dei verbum, w: Sobór Watykański II, Konstytucje, dekrety, deklaracje, Poznań 1967, nr 2 (dalej: KO).

${ }^{6}$ Katechizm Kościoła Katolickiego, Poznań 1994, nr 517.

${ }^{7}$ Niniejszą opinię potwierdza Tarcisio Stramare, który wskazuje, iż dokument podkreśla ścisły związek Józefa z misją zbawczą Odkupiciela. Zob. T. Stramare, A vent'anni dalla „Redemptoris custos", dz. cyt., s. 43. 
miały zbawczą skuteczność ${ }^{8}$. O ile życie publiczne Chrystusa przedstawione na kartach Ewangelii nie stanowi problemu, gdy chodzi o udzielanie się Bożego życia, o tyle opowiadania o Jego życiu ukrytym były przez niektórych niedoceniane $^{9}$. Jak podkreśla Tarcisio Stramare opowiadania o dzieciństwie Jezusa, będąc częścią nauczania apostolskiego, były traktowane przez Apostołów jako „tajemnice”, czyli narzędzia łaski ${ }^{10}$. Dlatego raz jeszcze należy podkreślić, że „całe życie Chrystusa, Objawiciela i Odkupiciela, to znaczy wszystkie wydarzenia i słowa, którymi to życie było utkane, zwykło się nazywać tajemnicą i historią zbawienia" 11 .

Podobnym ujęciem charakteryzuje się adhortacja apostolska Jana Pawła II wskazująca, że:

Ewangelie jasno ukazują, na czym polegały ojcowskie obowiązki Józefa wobec Jezusa. W istocie bowiem zbawienie, które przychodzi poprzez człowieczeństwo Jezusa, realizuje się poprzez gesty codziennego życia rodzinnego, w niczym nie naruszając owego „uniżenia” właściwego ekonomii wcielenia. Ewangeliści z wielką pieczołowitością ukazują, że w życiu Jezusa nic nie było dziełem przypadku, ale wszystko dokonało się zgodnie z planem ustalonym przez Boga (RC 8).

Jan Paweł II wymienia i charakteryzuje ponadto epizody z życia Józefa i Jezusa, które zostają opisane w komentarzach do Ewangelii Dzieciństwa autorstwa Tarcisio Stramare ${ }^{12}$. Powyższe przesłanki pozwalają wysnuć przypuszczenie o możliwym wpływie włoskiego teologa na redakcję papieskiej adhortacji ${ }^{13}$.

Zatem, należy raz jeszcze podkreślić, że postać św. Józefa została przedstawiona w perspektywie chrystocentrycznej i soteriologicznej, która umożliwiła Janowi Pawłowi II zaakcentowanie współpracy Józefa z Nazaretu ze zbawczą wolą Bożą oraz udzielania się łaski Bożej poprzez słowa i czyny Jezusa.

${ }^{8}$ T. Stramare, Ewangelia tajemnic ukrytego życia Jezusa (Mateusz i Lukasz 1-2), dz. cyt., s. 21.

9 Tamże, s. 23.

10 Tamże.

11 Tamże.

12 Jan Paweł II wymienia: spis ludności, narodzenie w Betlejem, obrzezanie, nadanie imienia, ofiarowanie Jezusa w świątyni, ucieczkę do Egiptu, Jezus w świątyni. Zob. RC 9-16. Natomiast T. Stramare wymienia: narodziny, obrzezanie Jezusa, Epifanię, ofiarowanie w świątyni, ucieczkę do Egiptu, ukryte życie Jezusa, wychowanie Jezusa, odnalezienie Jezusa w Świątyni. Zob. T. Stramare, Ewangelia tajemnic ukrytego życia Jezusa (Mateusz i Łukasz 1-2), dz. cyt., s. 24-25.

${ }^{13}$ Postawioną hipotezę będzie można udowodnić po odtajnieniu rękopisów dokumentów papieskich znajdujących się w Archiwum Watykańskim. W chwili obecnej można jedynie zaznaczyć rysujące się podobieństwa. 


\section{Józef w tajemnicy Chrystusa}

\section{Perspektywa historiozbawcza}

W analizowanym dokumencie dominuje perspektywa, która ukazuje „pokorną, dojrzałą służbę Józefa w zbawczej ekonomii” (RC 1). Wobec rozterek i wątpliwości odnośnie „cudownego macierzyństwa Maryi” (RC 3) spotyka się $\mathrm{z}$ interwencją anioła, który objawia mu prawdę o Dziecięciu oraz zleca mu misję nadania imienia Jezus, co oznaczało ,powierzenie mu funkcji ziemskiego ojca w stosunku do Syna Maryi” (RC 3).

Odpowiedzią Józefa na objawioną przez niebieskiego posłańca wolę Bożą było posłuszeństwo wiary. Postawa ta upodabniała go do swej Oblubienicy, gdyż okazał ,gotowość woli, wobec tego, czego odeń żądał Bóg przez swego Zwiastuna" (RC 3). Posłuszeństwo wiary Józefa i Maryi sprawiło, że stali się oni pierwszymi powiernikami tajemnicy Boga żywego (RC 5).

Józef, uczestnicząc w szczytowym etapie samoobjawiania się Boga w Chrystusie, wspierał swoją Oblubienicę w wierze, dzieląc trud ziemskiego pielgrzymowania (RC 6). Dzięki wierze i posłuszeństwu wkroczył w realizację zbawczej ekonomii wyrażonej w epizodach zapisanych na kartach Ewangelii: spis ludności, narodzenie w Betlejem, obrzezanie i nadanie imienia, ofiarowanie w świątyni, ucieczka do Egiptu, odnalezienie Syna w świątyni i życie ukryte w Nazarecie.

Józef, wędrując do Betlejem z powodu spisu ludności i dokonując zapisu, potwierdził przynależność Jezusa do rodzaju ludzkiego, stając się jednocześnie uprzywilejowanym, naocznym świadkiem Jego narodzenia (RC 10).

Obrzęd obrzezania, dokonywany przez ojca, przywołujący przymierze między Bogiem a Abrahamem (RC 11), łączył się z nadaniem imienia dziecku, co w świetle prawa potwierdzało ojcostwo Józefa (RC 12). Do obowiązków religijnych ojca należał także wykup pierworodnego syna ( $Ł k$ 2,22nn) (RC 13).

Ucieczka Świętej Rodziny do Egiptu ukazała Józefa jako powiernika i współpracownika opatrznościowej tajemnicy Bożej (RC 14). Natomiast jej powrót do Nazaretu został odczytany w perspektywie starotestamentalnego wyjścia Izraela $\mathrm{z}$ niewoli egipskiej (RC 14).

Zastosowana perspektywa historiozbawcza pozwoliła Janowi Pawłowi II na zinterpretowanie pobytu Maryi i Józefa w Nazarecie jako uczestnictwa w tajemnicy przygotowywania się Wcielonego Słowa do mesjańskiego posłannictwa (RC 15). Do zadań patriarchy należało nie tylko „żywienie i odziewanie Jezusa” czy też „nauczenie Go Prawa i zawodu”, ale również Jego wychowanie (RC 16).

Posłuszeństwo $\mathrm{w}$ wierze Józefa sprawiło, że pozostał do końca wierny Bożemu powołaniu, wypełniając wolę Bożą w swoim życiu (RC 17): „uczynił tak, jak mu polecił anioł Pański” (Mt 1,24). Realizacja polecenia stała się dla niego początkiem drogi (RC 17). Mimo że Pismo Święte nie odnotowało żad- 
nego wypowiedzianego przez niego słowa, to jednak milczenie, stając się jeszcze bardziej wymowne, świadczy o jego sprawiedliwości (RC 17).

\section{Ojciec}

Kolejnym elementem obrazu jest temat ojcostwa, które zostało integralnie powiązane z małżeństwem. Bóg bowiem ,wybrał Józefa na małżonka Maryi po to, by zapewnić Jezusowi ojcowską opiekę" (RC 7). Chociaż Jezus nie narodził się z nasienia Józefa, to jednak małżeństwo zapewniało prawną podstawę ojcostwa Józefa (RC 7). Syn Maryi stał się synem Józefa na mocy małżeńskiej więzi, która ich łączyła (por. RC 7).

Ojcostwo Józefa stanowiło formę posługi i misji wobec Jezusa, stając się w ten sposób uczestnictwem w ekonomii odkupienia (RC 8) poprzez złożenie samego siebie w ofierze, swojego życia, swojej pracy, swego serca i wszelkich zdolności (por. RC 8). Jego ofiara była odpowiedzią na wolę Boga, który jemu powierzył opiekę nad życiem Zbawiciela.

Wybór Józefa wiązał się z uzdolnieniem do pełnienia takiej posługi. Bóg, powierzając Józefowi ojcowską władzę nad Jezusem, obdarował go miłością ojcowską (RC 8). Jego zadaniem było wychowywanie Syna, polegające na wprowadzeniu Go w świat, przy zachowaniu praw Boskich i ludzkich, oraz opieka nad życiem Jezusa (RC 8).

Ojcostwo Józefa było akceptowane przez Jezusa. Wiązało się z tajemnicą wcielenia. Przyjęcie ludzkiej natury przez Odwieczne Słowo oznaczało w konsekwencji przyjęcie wszystkiego co ludzkie, w tym ludzkiego ojcostwa Józefa (RC 21).

\section{Oblubieniec}

Pismo Święte zwraca uwagę na sprawiedliwość Józefa. Jan Paweł II interpretuje ją jako wypełnianie woli Bożej objawionej przez anioła Pańskiego. Boski zamysł przewidywał jego małżeństwo z Maryją (RC 18). Słowa niebieskiego posłańca skierowane do Józefa objawiają, że zaślubiny Józefa z Maryją dokonały się zgodnie z wolą Bożą. Co więcej, ukazują prawdę o jego własnym powołaniu (RC 19). Bóg potwierdził i umocnił więź łączącą Józefa ze swoją małżonką. Odpowiadając na słowa anioła, Józef na nowo przyjął Maryję „w miłości poczętej z Ducha Świętego” (RC 19). W ten sposób miłość ludzka łącząca dwoje małżonków została ubogacona Bożą miłością, co w konsekwencji doprowadziło do pogłębienia tego, co w człowieku piękne i godne, ,co nosi znamiona wyłącznego zawierzenia i przymierza osób, autentycznej komunii" (RC 19). Józef odnalazł w Duchu Świętym źródło miłości oblubieńczej (RC 19). Jest ona dziewicza i oblubieńcza zarazem. Duch Święty, kształtując miłość oblubieńczą małżonków, pogłębia wszystko, co jest godne i piękne (RC 19). 
Oblubieńcza miłość Józefa zakładała postawę ofiary z siebie oraz bezinteresowną miłość do Maryi, która wyraziła się w Jej przyjęciu oraz w szacunku okazanym Jej wyłącznej przynależności do Boga (RC 20). Jego małżeństwo z Maryją stało się dla niego źródłem wielu łask oraz szczególnej godności Józefa i jego praw wobec Jezusa (RC 20). Jako oblubieniec stał się towarzyszem Jej życia, świadkiem Jej dziewictwa oraz obrońcą Jej cnoty (RC 20). Więź z Maryją sprawiła, że Józef ,najbardziej się zbliżył do wyjątkowej godności jaką cieszyła się Bogurodzica" (RC 20).

\section{Cieśla}

Kolejnym elementem obrazu łączącym się z postacią Józefa z Nazaretu była wykonywana przez niego praca. Jako cieśla zapewniał Świętej Rodzinie utrzymanie podczas pobytu w Nazarecie. Józef odegrał decydujący wpływ na ukształtowanie się w synu Maryi cnoty pracowitości (RC 23), cnoty, która pogłębiała Jego człowieczeństwo (RC 21). Cieśla z Nazaretu uczył pracy Syna Bożego, który przyjmując człowieczeństwo w tajemnicy wcielenia, przybliżył „ludzką pracę do tajemnicy Odkupienia” (RC 22). Józef przypomniał nam, że „aby być dobrym i autentycznym naśladowcą Chrystusa, nie trzeba dokonywać wielkich rzeczy, wystarczy posiąść zwyczajne, autentyczne ludzkie cnoty" (RC 24). Posłuszeństwo Jezusa okazywane rodzicom wyrażało się między innymi w Jego uczestnictwie w pracy Józefa i nauce zawodu.

\section{Człowiek życia wewnętrznego}

Jan Paweł II, charakteryzując postać opiekuna Jezusa, zwrócił uwagę na jego milczenie, które odsłaniało istotny aspekt jego osobowości - prymat życia wewnętrznego. Pobyt w Nazarecie sprawił, że Józef na co dzień obcował z tajemnicą Wcielonego Słowa. Jeśli miłość Boża poprzez człowieczeństwo Jezusa promieniowała na swoich rodziców, to znajdowała ona odpowiedź w postawie Józefa. Jego ojcowska miłość była odpowiedzią na synowską miłość Jezusa. Ta wzajemna więź oparta na miłości spowodowała przezwyciężenie pozornego napięcia między życiem czynnym a kontemplacyjnym (RC 27). Jak zauważył Ojciec Święty, Józef przeżywał zarówno czystą kontemplacyjną miłość Boskiej Prawdy promieniującej z człowieczeństwa Chrystusa, jak i czystą miłość służby, której domagała się opieka nad człowieczeństwem Jezusa (RC 27).

Realizacja tego specyficznego powołania nie byłaby możliwa, gdyby nie całkowita ofiara, jaką złożył Józef. Obejmowała ona „podporządkowanie Bożym zamysłom swojej wolności, swojego szczęścia małżeńskiego, akceptując wyznaczone jemu miejsca w rodzinie oraz ciężar odpowiedzialności, rezygnując z naturalnej miłości małżeńskiej” (RC 26). 


\section{Józef w tajemnicy Kościoła}

Druga część dyptychu odnosi się do roli i miejsca Józefa w tajemnicy Kościoła. Adhortacja przedstawia go jako patrona dla Kościoła naszych czasów. Jego opieka nad Mistycznym Ciałem Chrystusa została podkreślona dzięki zestawieniu wypowiedzi poprzedników papieża Wojtyły. Na przykład papież Pius IX uzasadnił ów tytuł wyjątkową godnością nadaną przez Boga oraz stałym i trwałym nabożeństwem, jakim Kościół otaczał Oblubieńca Dziewicy Maryi (RC 28).

Opiekuńcza posługa Józefa w Kościele została wyjaśniona przez Leona XIII. Jak podkreślił papież, patriarcha był prawnym, naturalnym stróżem, opiekunem i obrońcą Świętej Rodziny (RC 28). Opieka św. Józefa łączy się z jego orędownictwem.

To orędownictwo, zaznacza papież, jest ustawicznie potrzebne Kościołowi nie tylko dla obrony przeciw pojawiającym się zagrożeniom, ale także (...) dla umocnienia go w podejmowaniu zadania ewangelizacji świata (RC 29).

Jednocześnie Kościół dostrzega w Józefie nie tylko orędownika, ale również wzór do naśladowania „nie tylko dla poszczególnych stanów życia, ale dla całej chrześcijańskiej wspólnoty" (RC 30). Staje się on dla wierzących wzorem posłuszeństwa w wierze, słuchania Słowa Bożego oraz współpracy w dziele zbawienia. Mając w pamięci, iż „Bóg powierzył młodość naszego Zbawiciela wiernej straży świętego Józefa", Kościół prosi Boga, aby pozwolił mu wiernie współpracować z dziełem zbawienia, zachowując wierność i czystość serca (RC 31).

\section{Źródła ikony}

Istotnym aspektem tworzonego przez Jana Pawła II obrazu św. Józefa były źródła, na których się oparł. Papież w swoim nauczaniu często odwołuje się do doktryny Soboru Watykańskiego II. Soborowe hasło powrotu do źródeł zostało zawarte w konstytucji apostolskiej Lumen gentium, stwierdzając:

Studiując pilnie pod przewodem Urzędu Nauczycielskiego Pismo święte, Ojców i doktorów oraz liturgie Kościoła, niechaj we właściwy sposób wyjaśniają dary i przywileje Błogosławionej Dziewicy, które zawsze odnoszą się do Chrystusa, źródła wszelkiej prawdy i pobożności ${ }^{14}$.

${ }^{14}$ Sobór Watykański II, Konstytucja dogmatyczna o Kościele Lumen gentium, w: Sobór Watykański II, Konstytucje, dekrety, deklaracje, Poznań 1967, nr 67. 
Wspomniane słowa, odnoszące się do Najświętszej Maryi Panny, zostały zaaplikowane do postaci św. Józefa.

Pierwszym i fundamentalnym źródłem adhortacji Redemptoris custos było Pismo Święte, szczególnie Ewangelie Mateusza i Łukasza w tym, co odnosiło się do Józefa. Klucz w lekturze dokumentu stanowią tajemnice życia Chrystusa ${ }^{15}$. Mają one swoją podstawę w wydarzeniu wcielenia (RC 1). Tajemnica (misterium) jest jednym $z$ trzech istotnych komponentów wchodzących w skład objawienia, którego szczytem jest Jezus Chrystus. Przyjęcie człowieczeństwa przez Odwieczne Słowo nadaje mu walor zbawczy. Zatem, całe życie Chrystusa jest tajemnicą (misterium), posiada zbawcze znaczenie ${ }^{16}$. Pomimo wyróżnienia w życiu Zbawiciela okresu ukrytego oraz okresu publicznego, nie można zapominać, że całe życie Jezusa posiada wartość zbawczą, w tym także tajemnice życia ukrytego.

Drugim istotnym źródłem papieskiego dokumentu jest nauczanie Soboru Watykańskiego II. Papież oparł się na doktrynie o objawieniu zawartej w konstytucji dogmatycznej Dei verbum. Dokument podkreśla, że:

plan objawienia urzeczywistnia się przez czyny i słowa wewnętrznie ze sobą powiązane, tak, że czyny dokonane przez Boga w historii zbawienia ilustrują i umacniają naukę oraz sprawy słowami wyrażone; słowa zaś obwieszczają czyny i odsłaniają tajemnicę w nich zawartą (KO 2).

Wynika z tego, że trzy elementy są powiązane z objawianiem się Boga: słowa, czyny oraz tajemnice. Jednocześnie, jak stwierdza ta sama konstytucja, „najgłębsza zaś prawda o Bogu i o zbawieniu człowieka jaśnieje nam przez to objawienie w osobie Chrystusa, który jest zarazem pośrednikiem i pełnią całego objawienia" "17. Stwierdzenie to przełożyło się na chrystocentryczny wymiar adhortacji. Tytuł Redemptoris custos ukazuje postać Józefa w perspektywie Chrystusa-Odkupiciela.

Jan Paweł II wykorzystał także inne dokumenty Urzędu Nauczycielskiego Kościoła. Są nimi: list apostolski Inclytum Patriarcham Piusa IX ${ }^{18}$, encyklika Quamquam pluries Leona XIII ${ }^{19}$ oraz jego list apostolski Neminem fugit ${ }^{20}$, motu

15 T. Stramare, A vent'anni dalla ,Redemptoris custos”, dz. cyt., s. 47.

${ }^{16}$ Katechizm Kościoła Katolickiego, dz. cyt., nr 517.

17 Tamże.

${ }_{18}$ Kongregacja Obrzędów, Dekret Quemadmodum Deus, (8 grudnia 1870): Pii IX P.M. Acta, cz. 1, t. 5, s. 282; Pius IX, List apostolski Inclytum Patriarcham, (7 lipca 1871), l.c., s. 331-335.

${ }^{19}$ Leon XIII, Encyklika Quamquam pluries, (15 sierpnia 1889): Leonis XIII P.M. Acta, IX(1890), s. 175-182; Leon XIII, Oratio ad Sanctum Josephum, dołączona do tekstu Encyklika Quamquam pluries, (15 sierpnia 1889): Leonis XIII P.M. Acta, IX(1890), s. 183.

${ }^{20}$ Leon XIII, List apostolski Neminem fugit (14 czerwca 1892), AAS 25(1892-1893), s. 149. 
proprio Bonum sane Benedykta $\mathrm{XV}^{21}$, encyklika Haurietis aquas Piusa XII ${ }^{22}$, orędzie radiowe Jana XXIII ${ }^{23}$, przemówienia Pawła VI ${ }^{24}$ oraz własne pisma ${ }^{25}$. Do wymienionych dokumentów należy dodać także wypowiedzi niektórych kongregacji Stolicy Apostolskiej ${ }^{26}$.

Kolejnym źródłem, które pojawia się w adhortacji, są pisma Ojców Kościoła oraz pisarzy chrześcijańskiego antyku. Jan Paweł II sięgnął po pisma: św. Ireneusza $^{27}$, św. Jana Chryzostoma ${ }^{28}$, św. Augustyna ${ }^{29}$, Orygenesa ${ }^{30}$. Nie zabrakło odniesień do dzieł średniowiecznych Doktorów Kościoła: św. Bernarda z Clairvaux $^{31}$ i św. Tomasza z Akwinu ${ }^{32}$.

Redemptoris custos zawiera także odniesienia do tekstów liturgicznych. Wynika z tego, że papież, tworząc obraz św. Józefa, sięgnął również po teksty liturgiczne ${ }^{33}$. Liturgia, wyrażająca wiarę ludu Bożego, stała się dla następcy św. Piotra źródłem teologicznej refleksji3i ${ }^{34}$

${ }^{21}$ Benedykt XV, Motu proprio Bonum sane, (25 lipca 1920): l.c., s. 313-317.

${ }^{22}$ Pius XII, Encyklika Haurietis aquas, (15 maja 1956), AAS 48(1956), s. 329-337; Pius XII, Orędzie radiowe do uczestników szkół katolickich Stanów Zjednoczonych, (19 lutego 1958), AAS 50(1958), s. 174; Pius XII, Przemówienie, (11 marca 1945), AAS 37(1945), s. 72; Pius XII, Przemówienie, (1 maja 1955), AAS 47(1955), s. 406.

${ }^{23}$ Jan XXIII, Orędzie radiowe (1 maja 1960), AAS 52(1960), s. 398.

${ }^{24}$ Paweł VI, Przemówienie (19 marca 1966): Insegnamenti, IV(1966), s. 110; Paweł VI, Przemówienie (19 marca 1969): Insegnamenti, VII(1969), s. 1268-1269; Paweł VI, Przemówienie do Ruchu „Equipes Notre-Dame”, (4 maja 1970), 7, AAS 62(1970), s. 431.

25 Jan Paweł II, Przemówienia z 9 i 16 stycznia, 20 lutego 1980: Insegnamenti, III/I(1980), s. 88-92, 148-152, 428-431; Jan Paweł II, Adhortacja apostolska Familiaris consortio, (22 listopada 1981), Libreria Editrice Vaticana 1981, 16.17.85: l.c., s. 98, 100, 189; Jan Paweł II, Encyklika Laborem exercens, (19 września 1981), 9, AAS 73(1981), s. 599n; Jan Paweł II, Adhortacja apostolska Christifideles laici, (30 grudnia 1988), 34, AAS 81(1989), s. 456.

${ }^{26}$ Kongregacja Obrzędów, Dekret Quemadmodum Deus, (8 grudnia 1870), s. 282-283; Kongregacja Obrzędów, Dekret Novis hisce temporibus, (13 listopada 1962), AAS 54(1962), s. 873.

${ }_{27}$ Irenaeus Lugdunensis, Adversus haereses, PG 7, IV 23,1.

${ }_{28}$ Ioannes Chrysostomus, In Matth. Hom, PG 57, V,3.

${ }^{29}$ Augustinus, De nuptiis et concupiscentia, PL 44, I,11,12.

30 Origenes, Hom. XI in Lucam, PG 13, 6.

${ }^{31}$ Bernardus Clarevallensis, Super „, Missus est”, PL 183, Hom. II, 16.

32 Thomas de Aquino, Summa Theologiae, II-II, q. 182, a. 1, ad 3.

${ }_{33}$ Missale Romanum, Collecta in „Sollemnitate S. Joseph Sponsi B.M.V.; Missale Romanum, Prex Eucharistica I; Missale Romanum, Prefatio in „Sollemniatate S. Joseph Sponsi B.M.V.; Collectio Missarum de Beata Maria Virgine, I, „Sancta Maria de Nazareth”, Prefatio; Missale Romanum, Collecta; Super oblata in „Sollemnitate S. Joseph Sponsi B.M.V.; Post communio in „Missa votiva S. Joseph".

${ }^{34}$ Missale Romanum, Collecta in „Sollemnitate S. Joseph Sponsi B.M.V.; Missale Romanum, Prefatio in „Sollemnitate S. Joseph Sponsi B.M.V.”; Misale Romanum, Prex Eucharistica I; Collectio Missarum de Beata Maria Virgine, I, „Sancta Maria de Nazareth”, Prefatio; Missale Romanum, Collecta; Super oblata in „Sollemnitate S. Joseph Sponsi B.M.V.”; Post communio in „Missa votiva S. Joseph". 


\section{Zakończenie}

Konkludując, należy stwierdzić, że teologiczny obraz św. Józefa, jaki Jan Paweł II przedstawił w swojej adhortacji apostolskiej, jest integralnie powiązany z nauczaniem Soboru Watykańskiego II, szczególnie z konstytucjami Dei Verbum oraz Lumen gentium. Postać świętego patriarchy została ukazana w tajemnicy Chrystusa i Kościoła. Józef został przedstawiony jako ojciec, oblubieniec, cieśla oraz człowiek kontemplujący Zbawiciela. Kościół upatruje w nim opiekuna, stróża i orędownika oraz wzór do naśladowania.

Jan Paweł II, idąc za wskazaniami soboru, rozwinął w swojej adhortacji perspektywę historiozbawczą, akcentując aktywną współpracę Józefa w wypełnianiu woli Bożej oraz jego ojcowską troskę i opiekę nad Świętą Rodziną.

Soborowe wezwanie powrotu do źródeł znalazło odzwierciedlenie w papieskiej adhortacji. Dokument opiera się na Piśmie Świętym, orzeczeniach Urzędu Nauczycielskiego Kościoła, jak również na wypowiedziach Ojców i Doktorów Kościoła. Papież wielokrotnie posłużył się tekstami liturgicznymi. To solidne oparcie się na źródłach sprawiło, że przedstawiony w adhortacji obraz św. Józefa jest pozbawiony przesady, fałszywej egzaltacji i pobożnościowej nadinterpretacji.

\section{Streszczenie}

Celem niniejszego opracowania jest ukazanie sposobu interpretacji postaci świętego patriarchy w adhortacji apostolskiej Jana Pawła II Redemptoris custos. Dokonana analiza pozwoliła stwierdzić, że teologiczny obraz św. Józefa zawarty w adhortacji jest integralnie powiązany z nauczaniem Soboru Watykańskiego II. Postać świętego patriarchy została ukazana w dwóch odsłonach: w tajemnicy Chrystusa i Kościoła. Z jednej strony Józef został przedstawiony jako ojciec, oblubieniec, cieśla oraz człowiek kontemplujący Zbawiciela. Z drugiej ukazano jego rolę w tajemnicy Kościoła jako opiekuna, stróża i orędownika oraz wzór do naśladowania. Godnym podkreślenia jest perspektywa historiozbawcza, dominująca w całym dokumencie, która pozwoliła zaakcentować aktywną współpracę Józefa w wypełnianiu woli Bożej. Soborowe wezwanie powrotu do źródeł znalazło odzwierciedlenie w dokumencie dzięki licznym odniesieniom do: Pisma Świętego, orzeczeń Urzędu Nauczycielskiego Kościoła, wypowiedzi Ojców i Doktorów Kościoła. Papież sięgnął także po teksty liturgiczne. Oparcie się na takich źródłach sprawiło, że przedstawiony w adhortacji obraz św. Józefa jest pozbawiony przesady i fałszywej egzaltacji.

\section{Słowa kluczowe}

św. Józef, Jan Paweł II, Sobór Watykański II, Redemptoris custos, źródła 


\section{The theological icon of St. Joseph as perceived by John Paul II}

\section{Summary}

The aim of this study is to analyze the way of interpreting the figure of St. Joseph in the apostolic exhortation of John Paul II Redemptoris custos, emphasizing the sources that the pope used in the construction of the theological image. The analysis made it possible to conclude that the theological image of St. Joseph included in the exhortation is integrally connected with the teaching of the Second Vatican Council. The figure of the Patriarch is shown in two sections: in the mystery of Christ and the Church. On the one hand, Joseph was introduced as a father, bridegroom, carpenter, and a contemplative man of the Savior. On the other hand, it shows his role in the mystery of the Church as a guardian and intercessor, as well as a model to follow. It is worthy to note the perspective of salvation history, dominant in the entire document, which allowed to emphasize Joseph's active cooperation in fulfilling God's will. The conciliar call to return to the sources is evidenced in the document thanks to numerous references to Sacred Scripture, to the documents of the Church's Magisterium, to the statements of the Fathers and Doctors of the Church and use of the liturgical texts. Such a solid reliance on sources meant that the image of St. Joseph is solid, without exaggeration and false exaltation.

\section{Keywords}

St. Joseph, John Paul II, Council of Vatican II, Redemptoris custos, sources

\section{Bibliografia}

Augustinus, De nuptiis et concupiscentia, PL 44, koll. 413-474.

Benedykt XV, Motu proprio Bonum sane, (25 lipca 1920): l.c., s. 313-317.

Bernardus Clarevallensis, Sermones Super Missus est, PL 183, 55-88.

Brzeziński D., Udziat świętego Józefa w zbawczych planach Boga w świetle adhortacji apostolskiej „,Redemptoris custos”, „Studia Liturgiczne” 12(2016), s. 13-22.

Cichosz W., Rumian Ł., Pedagogia Świętego Józefa w świetle adhortacji apostolskiej „,Redemptoris custos”, „Teologia i Człowiek” 50(2020)2, s. 65-90.

Collecta; Super oblata in „Sollemnitate S. Joseph Sponsi B.M.V.; Missale Romanum ex decreto Sacrosancti Oecumenici Concilii Vaticani II instauratum auctoritate Pauli PP. VI promulgatum, Ioannis Pauli PP. II cura recognitum, Editio typica tertia, Libreria Editrice Vaticana 2002, s. 433.

Collecta in „Sollemnitate S. Joseph Sponsi B.M.V.; Missale Romanum ex decreto Sacrosancti Oecumenici Concilii Vaticani II Instauratum auctoritate Pauli PP. VI promulgatum, Ioannis Pauli PP. II cura recognitum, Editio typica tertia, Citta del Vaticano 2002, s. 433.

Czamara W., Gtówne idee adhortacji apostolskiej Jana Pawła II „Redemptoris custos”, „Ateneum Kapłańskie” 132(1999), z. 1, s. 6-12. 
Czamara W., Główne idee adhortacji apostolskiej Jana Pawła II „Redemptoris custos”, „Collectanea Theologica” 69(1999), nr 1, s. 151-156.

Hadryś J., Święty Józef wzorem człowieka zatroskanego o życie w świetle „, Redemptoris custos”, w: Badźcie solidarni z życiem. W dziesiąta rocznice przemówienia Jana Pawła II w Kaliszu w obronie życia, red. D. Bryl, J. Troska, Poznań 2007, s. 137-149. Ioannes Chrysostomus, Commentarius in Matthaeum Evangelistam, PG 57, koll. 13-472; PG 58, koll. 471-794.

Irenaeus Lugdunensis, Adversus haereses, PG 7, koll. 447-1225.

Jan XXIII, Orędzie radiowe (1 maja 1960), AAS 52(1960), s. 398.

Jan Paweł II, Adhortacja apostolska Christifideles laici, (30 grudnia 1988), 34, AAS 81(1989), s. 456.

Jan Paweł II, Adhortacja apostolska Familiaris consortio, (22 listopada 1981), Libreria Editrice Vaticana 1981.

Jan Paweł II, Adhortacja apostolska Redemptoris custos, (15 sierpnia 1989), Libreria Editrice Vaticana 1990.

Jan Paweł II, Encyklika Laborem exercens, (19 września 1981), 9, AAS 73(1981), s. $599 \mathrm{n}$.

Jan Paweł II, Przemówienia z 9 i 16 stycznia, 20 lutego 1980, Insegnamenti di Giovanni Paolo II, vol. III/I (1980), Citta del Vaticano 1981, s. 88-92, 148-152, 428-431.

Katechizm Kościoła Katolickiego, Poznań 1994.

Kolinko R. M., Św. Józef wzorem życia wewnętrznego i patronem na nasze czasy dla osób konsekrowanych na podstawie adhortacji apostolskiej Jana Pawła II „,Redemptoris custos”, w: Święty Józef-Patron na nasze czasy. Akta X Międzynarodowego Kongresu Józefologicznego. Kalisz 27 września - 4 października 2009, Kalisz 2010, s. 705-712.

Kongregacja Obrzędów, Dekret Novis hisce temporibus, (13 listopada 1962), AAS 54(1962), s. 873.

Kongregacja Obrzędów, Dekret Quemadmodum Deus, (8 grudnia 1870): Pii IX P.M. Acta, cz. 1, t. 5, s. 282-283.

Leon XIII, Encyklika Quamquam pluries, (15 sierpnia 1889), Acta Sanctae Sedis IX(1890), s. 175-182.

Leon XIII, List apostolski Neminem fugit (14 czerwca 1892), Acta Sanctae Sedis 25(1892-1893) s. 8-10.

Leon XIII, Oratio ad Sanctum Josephum, dołączona do tekstu Encyklika Quamquam pluries, (15 sierpnia 1889): Leonis XIII P.M. Acta, IX(1890), s. 183.

Origenes, In Lucam, PG 13, koll. 1801-1910.

Paweł VI, Przemówienie (19 marca 1966): Insegnamenti di Paolo VI, vol. IV (1966), Citta del Vaticano 1967, s. 110.

Paweł VI, Przemówienie (19 marca 1969): Insegnamenti di Paolo VI, vol. VII (1969), Citta del Vaticano 1970, s. 1268 -1269. 
Paweł VI, Przemówienie do Ruchu „Equipes Notre-Dame”, (4 maja 1970), 7, AAS 62(1970), s. 431.

Pius IX, List apostolski Inclytum Patriarcham, (7 lipca 1871), Acta Sanctae Sedis 6(1871), s. 324-327.

Pius XII, Encyklika Haurietis aquas, (15 maja 1956), III, AAS 48(1956), s. 329-337.

Pius XII, Orędzie radiowe do uczestników szkół katolickich Stanów Zjednoczonych (19 lutego 1958), Acta Apostolicae Sedis 50(1958), s. 174.

Pius XII, Przemówienie (11 marca 1945), AAS 37(1945), s. 72.

Pius XII, Przemówienie (1 maja 1955), AAS 47(1955), s. 406.

Prefatio in „Sancta Maria de Nazareth”, Collectio Missarum de Beata Maria Virgine, Libreria Editrice Vaticana 1987, s. 32-33.

Prefatio in ,Sollemniatate S. Joseph Sponsi B.M.V.; Missale Romanum ex decreto Sacrosancti Oecumenici Concilii Vaticani II Instauratum auctoritate Pauli PP. VI promulgatum, Ioannis Pauli PP. II cura recognitum, Editio typica tertia, Citta del Vaticano 2002, s. 433-434.

Prex Eucharistica I; Missale Romanum ex decreto Sacrosancti Oecumenici Concilii Vaticani II Instauratum auctoritate Pauli PP. VI promulgatum, Ioannis Pauli PP. II cura recognitum, Editio typica tertia, Citta del Vaticano 2002, s. 348.

Sobór Watykański II, Konstytucja dogmatyczna o Kościele Lumen gentium, w: Sobór Watykański II, Konstytucje, dekrety, deklaracje, Poznań 1967, s. 105-170.

Sobór Watykański II, Konstytucja dogmatyczna o Objawieniu Bożym Dei verbum, w: Sobór Watykański II, Konstytucje, dekrety, deklaracje, Poznań 1967, s. 350-362.

Stramare T., A vent'anni dalla „,Redemptoris custos”, w: Święty Józef-Patron na nasze czasy. Akta X Międzynarodowego Kongresu Józefologicznego. Kalisz 27 września4 października 2009, Kalisz 2010, s. 37-50.

Stramare T., Die Theologie des Mysteriums - „Passwort” fur die Lekture von „, Redemptoris custos", w: Die Bedeutung des hl. Joseph in der Heilsgeschichte. Akten des IX. Internationalen Symposions uber den heiligen Joseph (25 September bis 2 Oktober 2005 Kevelaer/Deutschland), Frankfurt 2006, s. 243-256.

Stramare T., Ewangelia tajemnic ukrytego życia Jezusa (Mateusz i Łukasz 1-2), Poznań 2012.

Stramare T., San Giuseppe nel mistero di Dio, Casale Monferrato 1992.

Stramare T., Syn Józefa z Nazaretu, Kraków 1980.

Thomas de Aquino, Summa Theologiae, http:/www.corpusthomisticum.org [dostęp: 10.10.2021]. 